\title{
Coccidia of gallinaceous meat birds in Brazil
}

\author{
Coccídios de galináceos de corte no Brasil \\ Marcel Teixeira ${ }^{1 *}$; Antônio Diego Brandão $\mathrm{Melo}^{2}$; George Rego Albuquerque²; \\ Patrícia Tironi Rocha ${ }^{3}$; Jomar Patrício Monteiro ${ }^{1}$ \\ ${ }^{1}$ Empresa Brasileira de Pesquisa Agropecuária - Embrapa Caprinos e Ovinos, Sobral, CE, Brasil \\ ${ }^{2}$ Universidade Estadual de Santa Cruz - UESC, Campus Soane Nazaré de Andrade, Ilhéus, BA, Brasil \\ ${ }^{3}$ BRF Brasil Foods SA., São Paulo, SP, Brasil \\ Received November 10, 2014 \\ Accepted January 12, 2015

\begin{abstract}
Coccidiosis is a disease that limits the production and marketing of gallinaceous birds in North America, especially quails, pheasants and chukar partridges. Virtually no research has been conducted in South America on the causative agents of diseases among these birds, including coccidia. The aim of this work was to make first observations on Eimeria spp. in the chukar partridge Alectoris chukar and the grey quail Coturnix coturnix, which are reared for meat in Brazil. Fecal and tissue samples were collected from commercial farms and were examined for oocysts, gross and microscopic lesions or endogenous stages. From this examination, it was found that partridges raised in Brazil did not have any visible infection. However, grey quails presented mild infection and two Eimeria species that had previously been described in other birds were identified.
\end{abstract}

Keywords: Eimeria, infection, diagnosis, oocyst, morphology.

\section{Resumo}

A coccidiose é uma enfermidade limitante para a produção e comercialização de aves de corte na América do Norte, principalmente codornas, faisōes e a perdiz de chukar. Praticamente nenhuma pesquisa foi realizada na América do Sul sobre os agentes causadores de doenças nessas aves, incluindo coccídios. O objetivo deste trabalho foi realizar as primeiras observaçôes sobre Eimeria spp. em perdiz de chukar Alectoris chukar e codornas cinzentas Coturnix coturnix criadas para abate no Brasil. Amostras de fezes e de tecidos foram coletadas em granjas comerciais e examinadas para oocistos, lesóes macroscópicas e microscópicas ou estágios endógenos. Após o exame, verificou-se que a criação de perdizes, no Brasil, não tinha infecção visível. No entanto, as codornas cinzentas apresentaram uma infecção leve e foram identificadas duas espécies de Eimeria descritas anteriormente em outras aves.

Palavras-chave: Eimeria, infecção, diagnóstico, oocisto, morfologia.

*Corresponding author: Marcel Teixeira. Empresa Brasileira de Pesquisa Agropecuária - Embrapa Caprinos e Ovinos, Fazenda Três Lagoas, Estrada Sobral/Groaíras, Km 4, CP 145, CEP 62010-970, Sobral, CE, Brasil.

e-mail: marcel.teixeira.vet@gmail.com 


\section{Introduction}

In North America, a relatively large range of exotic gallinaceous birds have been introduced and domesticated in certain areas specifically for hunting. Differently, some of these gallinaceous birds have been reared in South America exclusively for meat. The most popular exotic meat birds belong to the family Phasianidae Horsfield, 1821, which includes species of pheasants, partridges, quails, ducks, geese and doves. The chukar partridge, Alectoris chukar Gray, 1930, is a short, round, greyish-brown Eurasian upland bird that has been introduced into many countries and is well established in the United States, Canada and New Zealand for game purposes (WOODARD, 2002). It has been introduced into Brazil because of its fast growth rate. Likewise, the common grey quail, Coturnix coturnix Linnaeus, 1758, is marketed in Brazil exclusively for meat, because it is slightly larger than the domestic Japanese quail (Coturnix japonica), which is used as an egg-layer. The grey quail originated in Asia Minor and was first domesticated in Europe, but it can be found around the world except in the Americas (BIGLAND et al., 1965). The exotic meat bird industry in Latin America is small and the majority of its flock is located in the state of Santa Catarina in southern Brazil.

It is common knowledge that the parasite with the most negative impact on the economic avian industry worldwide is Eimeria. In North America, it is a major limitation to the production and marketing of bobwhite quails, ring-neck pheasants and chukar partridges (DUSZYNSKI \& GUTIÉRREZ, 1981; KEENE \& SCHWARTZ, 1984; RUFF, 1985). Virtually no research has been conducted on the causative agents of diseases of grey quails and chukar partridges in South America, including coccidia. The aim of this work was to make preliminary observations on Eimeria spp. from exotic gallinaceous meat birds marketed in Brazil.

\section{Materials and Methods}

This study was conducted on commercial farms integrated with or belonging to BRF S.A., the largest poultry company and the only one raising exotic meat birds in Brazil. The average production was around 50,000 chukar and 510,000 quails, slaughtered weekly at the company's abattoir located in Videira, Santa Catarina.

There was a single chukar farm with a flock separated into categories: three sheds for mothers consisting of wired cages for rearing birds from the age of twelve weeks onwards; and seven sheds for meat birds in which they were reared on the floor in wood shavings between the ages of 1 and 77 days. There were three quail farms, which were also separated into categories: four sheds for mothers, containing caged birds from the age of six weeks onwards and seven sheds for meat birds in which they were kept on bed litter between the ages of 1 and 35 days. All the sheds of all the chukar and quail flocks were studied. While prophylactic anticoccidial treatments were provided by the company to both chukar and quails, the regimen, type of drugs and doses used were not revealed.

Fecal samples from the meat sheds were collected from different points in the bed litter $(\mathrm{n}=20)$. In the mothers' sheds, samples were collected from each cage. A total of 11 sheds on the chukar farm and 33 sheds on the quail farms were sampled. All the samples were kept in plastic bags under refrigeration for transportation purposes. Four birds from each shed were randomly selected to be necropsied for lesion scoring and to collect tissue samples from the duodenum, jejunum, ileum and caeca. The tissue samples were fixed in $10 \%$ buffered formalin.

The fecal samples were sieved and stored at room temperature for sporulation in a thin layer of $2.5 \% \mathrm{w} / \mathrm{v}$ potassium dichromate. Oocysts were recovered from the feces after seven days of sporulation, by means of centrifugation in Sheather's solution. The oocysts were photographed for morphological analysis, under an Olympus BX 51 microscope coupled with an Olympus DP71 camera, using the Image-Pro Express 6 software for measurements (CARVALHO et al., 2011). Morphological identification was performed using oocyst length, width, shape index and inner features (DUSZYNSKI \& WILBER, 1997). To study the endogenous stages using optical microscopy, tissue samples were prepared in Histosec $^{\circledast}$ (Merck), sectioned at a thickness of $5 \mu \mathrm{m}$ and stained with periodic acid-Schiff.

\section{Results}

All the fecal samples from chukar partridges were negative for Eimeria oocysts. This result was confirmed by means of gross and microscopic examination, which showed that lesions or endogenous stages of Eimeria were absent from the tissue samples. These findings, together with the flock history and lack of clinical signs, suggest that chukar partridges reared in Santa Catarina do not have any visible coccidial infection. The fecal samples from all the quail farms were positive for Eimeria, but the oocyst numbers were very low. According to the morphological characteristics of the oocysts found (Table 1), two Eimeria species that had previously been described were identified in the quail samples (Figure 1). The most prevalent of these was E. bateri Bathia, Pandey \& Pande, 1965 (80.31\%), followed by E. tsunodai Tsutsumi, 1972 (9.69\%). No specific macro and microscopic lesions were observed in the tissues from the quails. Endogenous stages were observed mostly in sections from the upper and descending small intestine of quails. The parasites were located at the base of the villi, towards the glands. Occasional mature schizonts (mean size $8.7 \times 7 \mu$ ) were observed within the duodenum and ileum sections of young meat quails (23 days of age). They were generally located above the nucleus of the host cell. Gametocytes occurred throughout the small intestine but were more concentrated in the jejune of meat quails. Mature macrogametocytes (mean size $20.5 \times 11 \mu$ ) were more numerous than microgametocytes (mean size $19.8 \times$ $12 \mu$ ). No schizonts or gametocytes were observed in the sections from the intestine of adult caged quails.

\section{Discussion}

The prevalence and identity of the coccidia of exotic meat birds in the Brazilian poultry industry has never been assessed. Coccidiosis is the most frequent parasitic disease of the poultry industry worldwide and it is uncommon to find Eimeria-free flocks 


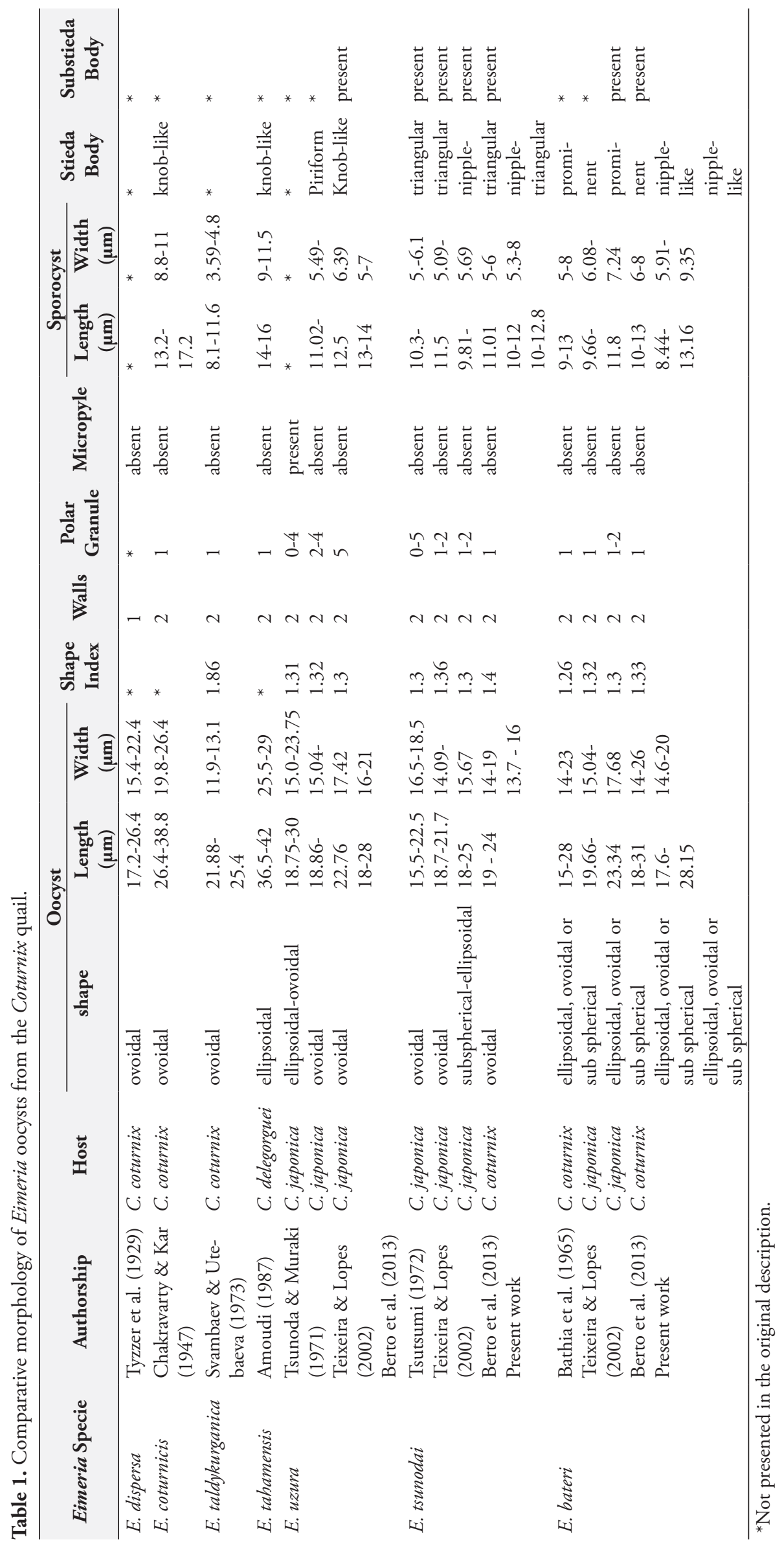



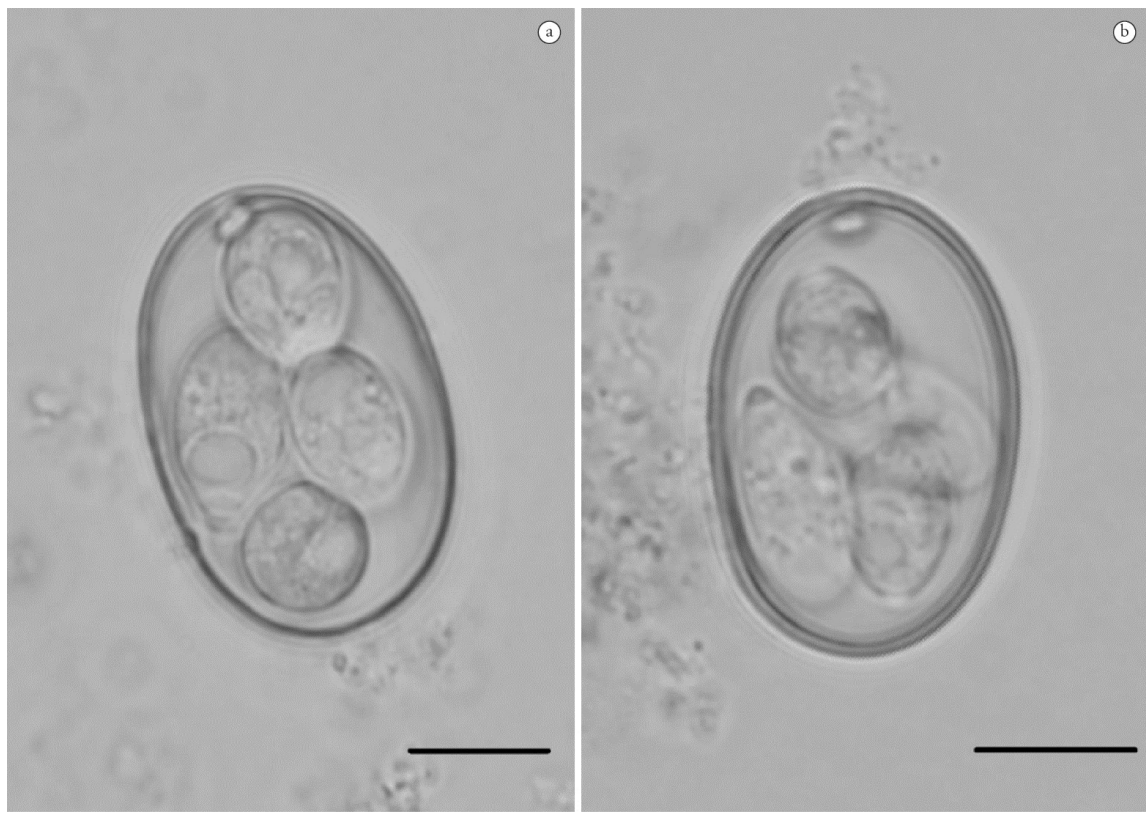

Figure 1. Sporulated oocysts of (a) Eimeria bateri and (b) E. tsunodai in Sheater's solution (scale bar $=10 \mu \mathrm{m})$.

(RUFF et al., 1984). However, according to the data presented here, coccidiosis is very well controlled in both the chukar and the quail farms in Santa Catarina, Brazil. The absence of infection in the chukar partridges could be due to the fact that these birds were introduced through egg importation from Europe. Consequently, no infected birds were introduced into Brazil. Moreover, egg hatching takes place under restricted conditions without any presence of circulating Eimeria species that might be able to infect these birds. This is probably due to host specificity (BIGLAND et al., 1965; EDGAR et al., 1964; SHAH \& JOHNSON, 1971; LONG \& MILLARD, 1979; FAYER, 1980; LONG \& JOYNER, 1984). Furthermore, prophylactic use of anticoccidial drugs and biosecurity measures may also have strengthened the limitation of infection among these chukar partridges.

Making a morphological diagnosis of Eimeria is often difficult because of similarities in oocyst morphology and infection sites. According to Ruff (1986), the taxonomic status of game bird coccidia is still in disarray, because different hosts may harbor different Eimeria species and cross-infections may not be entirely ruled out. This problem might be reduced through development of novel diagnostic methods (KUCERA \& REZNICKY, 1991; DAUGSCHIES et al., 1999). However, application of molecular diagnostic techniques depends on construction of PCR primers for detecting and distinguishing Eimeria spp. This technology remains unavailable for most exotic birds (GERHOLD et al., 2011). Thus, morphological differentiation in association with assessment of host specificity is still useful in characterizing Eimeria.

In Coturnix quails, six Eimeria species are known (Table 1) and three have been reported in Brazil (TEIXEIRA et al., 2004; BERTO et al., 2013). Eimeria bateri, a parasite originally described from Indian quails, seems to be well distributed worldwide (SHAH \& JOHNSON, 1971). This species was found to be able to infect and develop its entire life cycle in Japanese quails (NORTON \& PEIRCE, 1971). However, there are very few acceptable records of transmission of Eimeria species from one host genus to complete development in another, with the exception of situations that may reflect a close systematic relationship between two hosts (DORAN, 1978; LONG \& JOYNER, 1984). In a similar situation, Japanese quails were infected in a laboratory with $E$. dispersa, which is known to be a parasite of partridges and grey quails, but not of chickens or turkeys (EDGAR et al., 1964). Because Coturnix coturnix and Coturnix japonica are phylogenetically related birds, E. bateri and E. tsunodai may infect both hosts.

The other four species that have been described in Coturnix quails have oocysts that differ from those reported here. The oocysts of $E$. dispersa are slightly larger, have no polar granule and have a single wall. Those of E. coturnicis are considerably larger and contain sporocysts in which the sporozoites lie at opposite poles along the transverse axis and residuum is present. Oocysts of E. uzura, E. tahamensis and E. taldykurganica also differ in size, shape and shape index from those described here.

The presence of endogenous stages within the small intestine of young quails seen in our study was concordant with the form and location described in previous life cycle studies (NORTON \& PEIRCE, 1971; TSUTSUMI, 1972). This also suggests that young quails reared on the floor are more susceptible to infection. Even in situations of mild infection, constant monitoring of Eimeria incidence is necessary, particularly in younger categories, since this represents a threat to the livestock business if left unchecked.

\section{Acknowledgements}

The authors would like to thank to Walter Leira Teixeira Filho and Fabiana Lessa Silva for the preparation of histologic sessions of this study. This research project was conducted under the supervision of and was fully sponsored by the National Research Council (CNPQ) and the Research Support Foundation of the State of Bahia (FAPESB), in Brazil. 


\section{References}

Amoudi MA. Eimeria tahamensis N. sp. (Apicomplexa: Eimeriidae) from the Arabian quail (Coturnix delegorguei arabica). J Protozool 1987; 34(4): 455-456. http://dx.doi.org/10.1111/j.1550-7408.1987.tb03214.x. PMid:3430411

Bathia BB, Pandey TP, Pande BP. Eimeria bateri n. sp. from Indian common quail (Coturnix coturnix coturnix). Indian J Microbiol 1965; 5(1): 61-64.

Berto BP, Borba HR, Lima VM, Flausino W, Teixeira-Filho WL, Lopes CWG. Eimeria spp. from Japanese quails (Coturnix japonica): new characteristic features and diagnostic tools. Pesqui Vet Bras 2013; 33(12): 1441-1447. http://dx.doi.org/10.1590/S0100-736X2013001200008.

Bigland CH, Da Massa AJ, Woodard AE. Diseases of Japanese quail (Coturnix coturnix japonica) - A flock survey and experimental transmission of selected avian pathogens. Avian Dis 1965; 9(2): 212-219. http://dx.doi. org/10.2307/1588003.

Carvalho FS, Wenceslau AA, Teixeira M, Matos Carneiro JA, Melo ADB, Albuquerque GR. Diagnosis of Eimeria species using traditional and molecular methods in field studies. Vet Parasitol 2011; 176(2-3): 95100. http://dx.doi.org/10.1016/j.vetpar.2010.11.015. PMid:21167646

Daugschies A, Imarom S, Bollwahn W. Differentiation of porcine Eimeria spp. by morphologic algorithms. Vet Parasitol 1999; 81(3): 201-210. http://dx.doi.org/10.1016/S0304-4017(98)00246-5. PMid:10190864

Doran DJ. The life cycle of Eimeria dispersa Tyzzer 1929 from the turkey in gallinaceous birds. J Parasitol 1978; 64(5): 882-885. http://dx.doi. org/10.2307/3279523. PMid:722458

Duszynski DW, Gutiérrez RJ. The coccidia of quail in the United States. JWildl Dis 1981; 17(3): 371-379. http://dx.doi.org/10.7589/0090-355817.3.371. PMid:7310946

Duszynski DW, Wilber PG. A guideline for the preparation of species descriptions in the Eimeriidae. J Parasitol 1997; 83(2): 333-336. http:// dx.doi.org/10.2307/3284470. PMid:9105325

Edgar SA, Waggoner R, Flanagan C. Susceptibility of Coturnix quail to certain disease producing agents common to poultry. Poult Sci 1964; 43(5): 1315.

Fayer R. Epidemiology of protozoan infections: the coccidia. Vet Parasitol 1980; 6(1-3): 75-103. http://dx.doi.org/10.1016/0304-4017(80)90039-4.

Gerhold RW, McDougald LR, Beckstead RB. Construction of PCR primers to detect and distinguish Eimeria spp. in northern bobwhites and a survey of Eimeria on gamebird farms in the United States. $J$ Parasitol 2011; 97(5): 892-895. http://dx.doi.org/10.1645/GE-2816.1. PMid:21612414

Keene OD, Schwartz LD. Prevalent diseases and medications most frequently used by the game bird industry, Results of a national survey. Poult Sci 1984; 63(1): 70.

Kucera J, Reznický M. Differentiation of species of Eimeria from the fowl using a computerized image-analysis system. Folia Parasitol (Praha) 1991; 38(2): 107-113. PMid:1937268.
Long PL, Joyner LP. Problems in the identification of species of Eimeria. J Protozool 1984; 31(4): 535-541. http://dx.doi.org/10.1111/j.1550-7408.1984. tb05498.x. PMid:6392531

Long PL, Millard BJ. Rejection of Eimeria by foreign hosts. Parasitology 1979; 78(2): 239-247. http://dx.doi.org/10.1017/S0031182000049271. PMid:471537

Norton CC, Peirce MA. The life cycle of Eimeria bateri (Protozoa, Eimeriidae) in the Japanese quail Coturnix coturnix japonicum. J Protozool 1971; 18(1): 57-62. http://dx.doi.org/10.1111/j.1550-7408.1971. tb03280.x. PMid:5552705

Ruff MD, Fagan JM, Dick JW. Pathogenicity of coccidia in Japanese quail (Coturnix coturnix japonica). Poult Sci 1984; 63(1): 55-60. http:// dx.doi.org/10.3382/ps.0630055. PMid:6701143

Ruff MD. Coccidiosis in gallinaceous gamebirds. In: MacDougald LR, Joyner LP, Long PL, editors. Research in Avian Coccidiosis. Athens: University of Georgia; 1986. p. 107-115.

Ruff MD. Life cycle and biology of Eimeria lettyae sp. n. (Protozoa: Eimeriidae) from the northern bobwhite, Colinus virginianus (L.). J Wildl Dis 1985; 21(4): 361-370. http://dx.doi.org/10.7589/0090-355821.4.361. PMid:4078970

Shah HL, Johnson CA. Eimeria bateri Bhatia, Pandey and Pande, 1965 from the Hungarian quail Coturnix c. coturnix in the United States and its attempted transmission to the chicken. J Protozool 1971; 18(2): 219-220. http://dx.doi.org/10.1111/j.1550-7408.1971.tb03310.x. PMid:5104608

Svambaev SK, Utebaeva MK. Coccidial infections of Phasianus cochicus mongolicus and Coturnix coturnix in Kazakhstan. Izv Akad Nauk Ser Biol 1973; 6: 62-68.

Teixeira M, Lopes CWG. Species of the genus Eimeria (Apicomplexa: Eimeriidae) from Japanese quails (Coturnix japonica) in Brazil and E. fluminensis for the preoccupied E. minima of this quail. Rev. Bras. Cienc. Vet. 2002; 9:53-56.

Teixeira M, Teixeira Filho WL, Lopes CWG. Coccidiosis in Japanese Quails (Coturnix japonica): Characterization of a naturally occurring infection in a commercial rearing farm. Braz J Poult Sci 2004; 6(2): 129-134.

Tsunoda K, Muraki Y. A new coccidium of Japanese quails: Eimeria uzura sp. nov. Nippon Juigaku Zasshi 1971; 33(5): 227-235. http://dx.doi. org/10.1292/jvms1939.33.227. PMid:5169460

Tsutsumi Y. Eimeria tsunodai sp. nov. (protozoa; Eimeriidae). A caecal coccidium of Japanese quails (Coturnix coturnix japonica). Nippon Juigaku Zasshi 1972; 34(1): 1-9. http://dx.doi.org/10.1292/jvms1939.34.1. PMid:5063025

Tyzzer EE, Theiler H, Jones E. Coccidiosis in gallinaceous birds. Am J Hyg 1929; 15(2): 319-393.

Woodard AE. Raising chukar partridge [online]. Okland: University of California; 2002. vol. 21321e [cited 2003 Jan 10]. Available from http:// anrcatalog.ucdavis.edu/ 